Nowoczesne Systemy Zarządzania Zeszyt 12 (2017), nr 1 (styczeń-marzec) ISSN 1896-9380, s. 143-152

Modern Management Systems Volume 12 (2017), No. 1 (January-March) ISSN 1896-9380, pp. 143-152

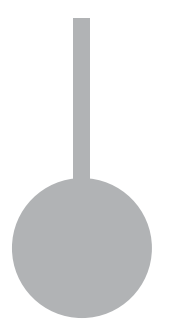

Instytut Organizacji i Zarządzania

Wydział Cybernetyki

Wojskowa Akademia Techniczna

w Warszawie

Institute of Organization and Management

Faculty of Cybernetics

Military University of Technology

\title{
Zmiany wewnątrz organizacji \\ w ocenie pracowników badanych podmiotów gospodarczych
}

\section{Changes within the organization according to the assessment of employees of examined traders}

\author{
Teresa Myjak \\ Państwowa Wyższa Szkoła Zawodowa w Nowym Sączu \\ Instytut Ekonomiczny, Zakład Zarządzania i Turystyki \\ e-mail: myjakt@wp.pl
}

\begin{abstract}
Abstrakt: W procesie planowania i wdrażania zmian wewnątrz organizacji fundamentalne znaczenie mają ludzie. Na każdym etapie procesu zmian istotną kwestią są postawy, zachowania i reakcje pracowników na dokonujące się zmiany. Celem publikacji jest przedstawienie zmian w przedsiębiorstwie oraz opinii pracowników na temat wprowadzonych zmian wewnątrz organizacji. Realizacja tak postawionego celu wymaga z jednej strony przeprowadzenia rozważań teoretycznych na temat zmian wewnątrzorganizacyjnych, a z drugiej - empirycznego przedstawienia podjętej problematyki. Analizując wyselekcjonowaną literaturę przedmiotu ukazano wybrane zagadnienia zmian wewnątrzorganizacyjnych. $\mathrm{Na}$ podstawie zrealizowanych w latach 2012-2014 badań własnych, przeprowadzonych w mikro, małych, średnich i dużych przedsiębiorstwach branży budowlanej sektora prywatnego, zlokalizowanych w województwie małopolskim, zaprezentowano fragment wyników badań obejmujący odczucia respondentów wobec dokonanych w tych przedsiębiorstwach zmian na przestrzeni pięciu ostatnich lat, poprzedzających okres badań. Zaprezentowano obszary zmian wewnątrzorganizacyjnych oraz ocenę tych zmian z perspektywy osób biorących udział w badaniach.
\end{abstract}

Słowa kluczowe: zmiany, wyniki badań własnych

Abstract: In the process of planning and implementing changes in the organization people are of fundamental importance. At each stage of the change process, the attitude, behavior and reactions of employees towards the changes is important. The aim of the publication is to present changes in the company and the employees' opinion about the changes within the organization. The implementation of this objective requires, on the one hand conducting theoretical considerations about the changes within the organization, and on the other - an empirical presentation of the undertaken issues. On the basis of analysis of selected literature we have shown some selected issues concerning changes within 
the issues. Using as a basis our own research completed in 2012-2014, conducted in the micro, small, medium and large enterprises of the construction industry in the private sector, located in the Malopolska province, we have presented a fragment of the results of studies involving feelings of respondents towards changes made in these companies over the last five years preceding the tests. We have put forward areas of change within the organization and the evaluation of these changes from the perspective of the people involved in the research.

Keywords: changes, the results of personal research

\section{Wstęp}

Od kilkunastu lat podnosi się kwestię, iż organizacje w coraz większym stopniu objęte są zmianami, które uważa się za jeden z kluczowych czynników wpływających na ich działalność i rozwój. Podkreśla się przy tym, że zmiany wewnątrz organizacji, którym niegdyś przypisywano wyjątkowy charakter, stały się obecnie tak powszechne, iż nie są już traktowane jako zło konieczne, ale wręcz jako immanentny składnik funkcjonowania, wywołany szybkimi i trudno przewidywalnymi przemianami zachodzącymi w otoczeniu (Czop, 2001, s. 225-239). Zarówno w teorii naukowej, jak i zbiorowej świadomości zmiana stała się dziś wszechobecna i realna (Wolfram-Krukowska, Ostrowska, 2012, s. 64-66). Zmiana umożliwia osiągnięcie czegoś nowego (Huczek, 2011, s. 53-73), obrazuje dynamikę i elastyczność organizacji, a poszukiwanie możliwości doskonalenia organizacji następuje w kierunku wprowadzania zmian w jej środowisku wewnętrznym w celu tworzenia potencjału rozwojowego (Pachura, Nitkiewicz, Kuraś, 2016, s. 29-40). Dlatego przedsiębiorstwa powinny być elastyczne, aby szybko dostosować swoje wnętrze do zmieniającego się otoczenia zewnętrznego (Oczkowska, 2014, s. 11-30).

Zmiany wewnątrzorganizacyjne należą do najtrudniejszych, gdyż zawsze dotyczą ludzi (Antoszkiewicz, 2008, s. 171). Biorąc pod uwagę indywidualne czynniki percepcji zmian oraz stopień poinformowania, ludzie będą wykazywać różne reakcje na zmiany (Sobka, 2014, s. 49). Wielowątkowość i wielowymiarowość zmian zachodzących wewnątrz organizacji powoduje bowiem zróżnicowane zachowania i reakcje ludzi na zmiany, którzy różnią się między sobą nie tylko pod względem cech socjologicznych, kulturowych, ale i demograficznych. Można zatem przyjąć, że największym problemem zmian wewnątrzorganizacyjnych są pracownicy przedsiębiorstwa, ponieważ już na etapie planowania zmian trudno przewidzieć, jakie będą indywidualne reakcje pracowników na zmiany.

\section{Pracownicy $w$ procesie zmian $w$ przedsiębiorstwie}

Proces zmian towarzyszy ludziom zarówno w życiu zawodowym, jak i pozazawodowym. Przez jednych mogą być postrzegane jako szansa rozwoju osobistego i zawodowego, a przez innych - jako wprowadzające destabilizację w dotychczas obowiązujących standardach organizacyjnych. Jeżeli zmiany wewnątrz organizacji 
są postrzegane przez pracowników jako szansa własnego rozwoju, wówczas stają się bodźcem aktywizującym ich do podejmowania kreatywnych działań oraz angażowania się w realizację wyznaczonych celów i zadań. Jeśli natomiast pracownicy dostrzegą w zmianach zagrożenie, spowoduje to niepokój, różnego rodzaju obawy czy stres, a w rezultacie reakcje powodujące opór wobec zmian.

Wydawać by się mogło, że skoro zmiany są naturalnym procesem, wpisanym w życie organizacji, zatem nie trzeba się uczyć ich wprowadzania. Takie rozumowanie jest błędne (Francik, 2003, s. 56). W rzeczywistości bowiem, chociaż zmiany są procesem naturalnym, a nie wyjątkowym (Barańska, 2014, s. 12), każda organizacja powinna dogłębnie przemyśleć i zaplanować zmiany wewnątrzorganizacyjne. Otoczenie przedsiębiorstwa ciągle się zmienia, więc i ono musi się zmieniać (Olejczyk-Kita, 2016, s. 13-19). W procesie zmian ogromną rolę przypisuje się pracownikom, ich wiedzy, umiejętnościom i doświadczeniu. Te atrybuty mają duże znaczenie w całym procesie zmian wewnątrzorganizacyjnych, od chwili pojawienia się i opracowania konceptualizacji zmian, poprzez uzmysłowienie wszystkim uczestnikom organizacji potrzeby wprowadzania zmian, aż do wdrożenia tych zmian w codzienną praktykę. „Organizacje, aby przetrwać muszą ciągle adaptować się do zmian rynkowych, reagować na potrzeby klientów, tworzyć nowe produkty" (Milewska, Woszczyk, 2012, s. 18-21), stąd też szczególnie od pracowników oczekuje się umiejętności dostosowania się do zmian i stosownego reagowania na nie. Każdy pracownik postrzega zmianę wprowadzoną w organizacji w sposób subiektywny, w związku z czym reakcje pracowników na zmiany mogą być bardzo zróżnicowane, od akceptacji po opór wobec zmian. Taki scenariusz stawia duże wyzwania przed decydentami, aby odpowiednio przygotować pracowników do zmian.

Wprowadzanie zmian wewnątrzorganizacyjnych wymaga przekształcania słów w czyny (Cannon, McGee, 2015, s. 27) oraz obiektywnego spojrzenia na korzyści, jak i straty z nich wynikające dla pracowników (tab. 1).

Tabela 1. Korzyści oraz zagrożenia wewnątrzorganizacyjnych zmian

\begin{tabular}{|c|c|}
\hline & $\mathbf{a}$ \\
\hline $\begin{array}{l}\text { podzielana przed wszystkich wizja i jasno } \\
\text { przedstawiona strategia przedsiębiorstwa; } \\
\text { zmienione zasady podejmowania decyzji; } \\
\text { określenie wspólnych wartości i orientacja } \\
\text { na klientów wewnętrznych i zewnętrznych; } \\
\text { (współ)praca zespołowa przebiegająca } \\
\text { w klimacie wzajemnego szacunku, poszu- } \\
\text { kiwania consensusu, relacji sieciowych } \\
\text { oraz partnerstwo; } \\
\text { - }\end{array}$ & $\begin{array}{l}\text { - utrata zaufania do kierownictwa, które } \\
\text { inicjuje takie pomysły, jak TQM, reengi- } \\
\text { neering, restrukturyzacja, projekty, praca } \\
\text { zespołowa, itp. Jeśli pomysły te nie są } \\
\text { dobrze wdrażane to ryzyko utraty zaufania } \\
\text { jest znaczne; } \\
\text { - utrata pracy przez pracowników (przez } \\
\text { niektórych nieuchronna); } \\
\text { - } \\
\text { pogorszenie sytuacji zawodowej } \\
\text { pracowników w przedsiębiorstwie. }\end{array}$ \\
\hline
\end{tabular}

Źródło: opracowanie własne na podstawie M. Sobka, Zmiany organizacyjne w teorii i praktyce, Politechnika Lubelska, Lublin 2014, s. 100-101 
Zarówno korzyści, jak i zagrożenia są związane ze złożonością procesu zmian wewnątrzorganizacyjnych, wynikających głównie z treści, charakteru i sposobu wprowadzania zmian. Złożoność ta jest wyznaczana przez wiele elementów, na co zwraca uwagę Cz. Zając. Wśród nich wylicza: czasową i przestrzenną strukturę procesu zmian, tj. występujące po sobie, często przenikające się etapy składające się na cykl zmiany oraz obszary funkcjonalno-merytoryczne i poziomy organizacyjne przedsiębiorstwa, na których te zmiany występują; liczbę osób wewnątrz i w otoczeniu przedsiębiorstwa zaangażowanych $\mathrm{w}$ proces i objętych zmianami, ich miejsce w hierarchii organizacyjnej, pozycję zawodową; skalę nakładów finansowych i organizacyjnych, zakres wykorzystania infrastruktury technologicznej, informatycznej i telekomunikacyjnej, a także konieczność przebudowy (w niektórych przypadkach) dotychczasowej kultury organizacyjnej przedsiębiorstwa (Zając, 2006, s. 28).

\section{Metodologia badań własnych}

Badania empiryczne, obejmujące m.in. zidentyfikowanie obszarów wprowadzonych zmian wewnątrz organizacji ${ }^{1} \mathrm{i}$ ich ocenę, zostały przeprowadzone $\mathrm{w}$ celowo dobranej próbie badawczej, składającej się z pracowników 27 firm z sektora MSP oraz dużych firm prywatnych. Celowy dobór próby badawczej został uwarunkowany specyfiką przedsiębiorstw działających w branży budowlanej. Techniką badawczą zaprezentowaną w niniejszej publikacji była technika ankiety, a narzędziem badawczym - kwestionariusz ankiety ${ }^{2}$. Dla potrzeb niniejszego opracowania zaprezentowano fragment wynikó $w^{3}$ kwestionariusza ankiety, w którym pytania obejmowały obszary wprowadzonych zmian oraz ocenę tych zmian przez ankietowanych. Proces badawczy został dostosowany do dyspozycyjności pracowników uczestniczących $\mathrm{w}$ badaniach i trwał dwa lata ${ }^{4}$. Uzależniony został z jednej strony od możliwości zebrania populacji badanej w jednym miejscu i czasie, w konkretnej firmie, a z drugiej

1 W niniejszej publikacji określenia: „organizacja”, „przedsiębiorstwo” oraz „firma” są używane zamiennie.

2 Przed przystąpieniem do badań, każda osoba miała możliwość zapoznania się z treścią kwestionariusza ankiety, a tym samym - podjęcia decyzji o uczestnictwie (lub nie) w badaniach. Do ankietowanych skierowano pytania otwarte, za pomocą których mogli wyrazić własne zdanie na dany temat, jak i zamknięte, z opcjami do wyboru przez respondentów.

3 Prezentację większej ilości wyników badań zawarto w pracy: T. Myjak, Wplywformy zatrudnienia na zachowania organizacyjne. Empiryczne studium porównawcze, Wyd. Adam Marszałek, Toruń 2014, s. 79 i dalsze.

4 Badania w przedsiębiorstwach zostały rozpoczęte jesienią 2012 roku, a zakończone latem 2014 roku. 
- od chęci uczestnictwa w badaniach ${ }^{5}$. Spośród 137 przebadanych osób, które miały staż pracy w badanej organizacji co najmniej pięć lat ${ }^{6} i$ wyraziły zainteresowanie badaniami, udzielając odpowiedzi na zadane pytania, ostatecznie 99 osób wskazało, iż zmiany wewnątrz organizacji dotyczyły ich w sposób bezpośredni. Pozostałe 38 osób stwierdziło, iż zmiany bezpośrednio ich nie dotyczyły ${ }^{7}$.

Analiza danych statystycznych, które najpierw zostały zakodowane, a następnie wprowadzone do programu Excel, została przeprowadzona za pomocą obliczeń wykonanych w programie Statistica. Zastosowanie tego programu pozwoliło wygenerować odpowiedzi respondentów dotyczących zmian wewnątrzorganizacyjnych w odniesieniu do ich cech demograficzno-społecznych. Jako metoda statystyczna została wykorzystana tzw. analiza jednowymiarowa. Odpowiedzi respondentów na konkretne pytanie charakteryzowano osobno, a rodzaj charakterystyk statystycznych uzależniono od skali pomiaru, w jakiej respondenci udzielali odpowiedzi na postawione pytanie.

\section{Ocena zmian wewnątrzorganizacyjnych z perspektywy pracowników badanych przedsiębiorstw}

W celu pokazania zróżnicowania odpowiedzi ankietowanych na zadane pytania dotyczące wprowadzonych zmian $w$ badanych przedsiębiorstwach oraz zaprezentowania oceny tych zmian z perspektywy pracowników, sporządzono zestawienie tabelaryczne wyników badań rezygnując z zamieszczania tzw. histogramów przedstawiających odpowiedzi respondentów na poszczególne pytania. Wyjaśnienia tej kwestii dokonano poprzez wykorzystanie zmiennych grupujących zawartych $\mathrm{w}$ metryczce. Zamierzeniem autorki było rozpoznanie obszarów wprowadzonych zmian w firmach poprzez analizę względem cech demograficzno-społecznych, ich ocena i na tej podstawie - przeprowadzenie wnioskowania. Osoby biorące udział w badaniach zostały poproszone najpierw o wskazanie obszarów, w których wprowadzono zmiany w przedsiębiorstwach (tab. 2), a następnie ocenę tych zmian (tab. 3).

5 Osoby biorące udział w badaniach były „rozproszone przestrzennie”. Jedni wykonywali pracę w siedzibie firm (głównie osoby zatrudnione na stanowiskach „,umysłowych”), a inni pracowali poza siedzibą - na stanowiskach ,fizycznych”, na terenie prowadzonych przez przedsiębiorstwa prac budowlanych. Nadmienić trzeba, iż nie wszystkie wytypowane do badań osoby zadeklarowały chęć uczestnictwa w badaniach, pomimo zgody ich przełożonych.

6 Ze względu na wysoką rotację ,pracowników budowlanych” zdecydowano, aby w badaniach uczestniczyły wyłącznie osoby, które pracują minimum 5 lat $\mathrm{w}$ badanych przedsiębiorstwach, i z takiej perspektywy czasowej - wskazały zmiany wewnątrzorganizacyjne, które ich objęły. Autorce zależało bowiem na uzyskaniu rzetelnych i wartościowych informacji związanych z problematyką badań.

7 Wobec powyższego w niniejszym opracowaniu nie uwzględniono opinii tych 38 osób. Jednocześnie przyjęto, że 100\% populacji badanej stanowią osoby bezpośrednio objęte zmianami, czyli dokładnie 99 osób. 
Tabela 2. Obszary wprowadzonych zmian $w$ przedsiębiorstwach ( $w \%$ odpowiedzi $i^{8}$ )

\begin{tabular}{|c|c|c|c|c|c|c|c|c|c|c|c|c|}
\hline \multirow{2}{*}{\multicolumn{2}{|c|}{$\overbrace{\begin{array}{l}\text { Zmienna } \\
\text { grupująca }\end{array}}$}} & \multicolumn{2}{|c|}{$\begin{array}{c}\text { Stan i struktura } \\
\text { zatrudnienia }\end{array}$} & \multicolumn{2}{|c|}{ Czas pracy } & \multicolumn{2}{|c|}{$\begin{array}{l}\text { Organizacja } \\
\text { pracy }\end{array}$} & \multicolumn{2}{|c|}{$\begin{array}{l}\text { Wynagrodze- } \\
\text { nie za pracę }\end{array}$} & \multicolumn{2}{|c|}{$\begin{array}{l}\text { Warunki } \\
\text { pracy }\end{array}$} & \multirow{2}{*}{$\begin{array}{c}\text { Liczność próby } \\
\text { (liczba odpowiedzi) }\end{array}$} \\
\hline & & Tak & Nie & Tak & Nie & Tak & Nie & Tak & Nie & Tak & Nie & \\
\hline \multirow{2}{*}{ Płeć } & Mężczyzna & 52 & 14 & 34 & 32 & 57 & 14 & 53 & 15 & 51 & 17 & 87 \\
\hline & Kobieta & 57 & 12 & 14 & 51 & 49 & 18 & 57 & 12 & 22 & 41 & 49 \\
\hline \multirow{4}{*}{ Wiek (w latach ) } & Do 25 & 33 & 17 & 0 & 50 & 50 & 0 & 33 & 17 & 33 & 17 & 6 \\
\hline & $25-35$ & 54 & 14 & 29 & 39 & 57 & 14 & 57 & 12 & 42 & 25 & 69 \\
\hline & $35-45$ & 59 & 12 & 32 & 37 & 59 & 15 & 56 & 17 & 46 & 24 & 41 \\
\hline & 45 i więcej & 50 & 10 & 15 & 45 & 40 & 25 & 50 & 20 & 25 & 35 & 20 \\
\hline \multirow{2}{*}{ Zamieszkanie } & Miasto & 61 & 8 & 20 & 43 & 47 & 18 & 51 & 18 & 33 & 25 & 51 \\
\hline & Wieś & 48 & 18 & 32 & 38 & 59 & 14 & 56 & 13 & 46 & 26 & 85 \\
\hline \multirow{3}{*}{ Wykształcenie } & Zawodowe & 46 & 17 & 38 & 33 & 50 & 21 & 54 & 17 & 50 & 21 & 24 \\
\hline & Średnie & 49 & 20 & 24 & 40 & 53 & 16 & 58 & 13 & 36 & 27 & 55 \\
\hline & Wyższe & 60 & 7 & 26 & 41 & 59 & 12 & 52 & 16 & 41 & 26 & 58 \\
\hline \multirow{2}{*}{ Stanowisko } & „Umysłowe” & 60 & 10 & 23 & 43 & 58 & 12 & 56 & 14 & 36 & 29 & 84 \\
\hline & „Fizyczne” & 44 & 20 & 34 & 34 & 48 & 22 & 52 & 16 & 48 & 22 & 50 \\
\hline \multirow{3}{*}{$\begin{array}{l}\text { Ogólny staż pracy } \\
\text { (w latach) }\end{array}$} & Do 5 & 38 & 38 & 0 & 75 & 63 & 13 & 63 & 13 & 25 & 50 & 8 \\
\hline & $5-10$ & 54 & 14 & 30 & 39 & 58 & 14 & 56 & 12 & 49 & 23 & 57 \\
\hline & 10 i więcej & 54 & 10 & 27 & 36 & 50 & 17 & 53 & 16 & 34 & 26 & 70 \\
\hline \multirow{3}{*}{$\begin{array}{l}\text { Staż w aktualnej firmie } \\
\text { (w latach) }\end{array}$} & Do 5 & 39 & 18 & 16 & 43 & 48 & 16 & 46 & 13 & 36 & 26 & 61 \\
\hline & $5-10$ & 56 & 17 & 39 & 39 & 59 & 17 & 63 & 12 & 54 & 22 & 41 \\
\hline & 10 i więcej & 74 & 3 & 31 & 34 & 63 & 11 & 60 & 20 & 34 & 29 & 35 \\
\hline
\end{tabular}

Źródło: opracowanie własne na podstawie wyników badań

8 Odpowiedzi respondentów nie sumują się do 100\%, ponieważ ankietowani wskazywali różne obszary zmian, wybierając więcej niż jeden wariant odpowiedzi na konkretne pytanie. 
Zmiany dokonujące się w otoczeniu nie pozostają bez znaczenia dla współczesnych organizacji, a w konsekwencji także dla partycypujących w tych zmianach pracowników. Ta trywialna konstatacja zawiera w sobie interesujące poznawczo spostrzeżenia po przeprowadzeniu analizy zmian. W obliczu przeobrażającego się środowiska zewnętrznego, przedsiębiorstwa zmuszone są wprowadzać zmiany wewnątrzorganizacyjne. Analiza danych ${ }^{9}$ zawartych w tabeli 2 wskazuje, iż badane organizacje wprowadziły zmiany w poszczególnych obszarach zadaniowych. Zmiana organizacji pracy objęła 57\% mężczyzn. Kobiety natomiast największych zmian doświadczyły w zakresie stanu i struktury zatrudnienia oraz wynagrodzenia za pracę (również po 57\% wskazań). Rozpatrując wiek badanych zauważono, iż młodzi pracownicy największą zmianę dostrzegli w zorganizowaniu pracy zawodowej (dokładnie 50\% wskazań). Podobnie było w drugiej grupie wiekowej (25-35 lat). Tutaj także największa zmiana wiązała się z organizacją pracy, a w ślad za tym - zmiana wysokości wynagrodzenia (również 57\%). Zmiana stanu i struktury zatrudnienia oraz wynagrodzenia za pracę objęła połowę najstarszych pracowników (dokładnie 50\%). Należy zauważyć, że zmiany dokonujące się obecnie w procesach rozwojowych w organizacji powodują, iż dużą wagę przywiązuje się do kompetencji pracowniczych (Jabłoński, 2015, s. 109-131). Nieustanne rozwijanie się i podnoszenie posiadanych kompetencji spowodowane jest podążaniem za zmianami (Myszka, 2016, s. 87-102). Zmiana zatem w stanie i strukturze zatrudnienia w badanych przedsiębiorstwach mogła być spowodowana tym czynnikiem. Analiza pozostałych zmiennych grupujących wskazuje, że blisko $2 / 3$ pracowników mieszkających w mieście także wskazało na zmianę stanu i struktury zatrudnienia. Podobny odsetek mieszkających na wsi wytypował zmianę organizacji pracy (59\%). Jeżeli chodzi zaś o wykształcenie, niemalże wszystkie grupy badanych wyszczególniły zmiany poziomu wynagrodzenia. Zmiana wynagrodzenia została także wskazana przez osoby zajmujące zarówno stanowiska „umysłowe” (56\%), jak i „fizyczne” (52\%). Osobom z ogólnym stażem pracy do 10 lat również zmieniono organizację pracy oraz wysokość wynagrodzenia, a osoby mające staż pracy powyżej 10 lat wskazały na zmianę stanu i struktury zatrudnienia (54\%). Jeżeli chodzi o staż pracy w aktualnej firmie, odpowiedzi respondentów nie różniły się znacząco.

Wnioski z przeprowadzonej analizy sprowadzają się do wskazania, iż zmienne grupujące zróżnicowały odpowiedzi respondentów w zakresie wprowadzonych zmian w organizacji. To zróżnicowanie mogło być spowodowane specyfiką branży budowlanej, którą cechuje m.in. sezonowość prac budowlanych, przejawiająca się intensyfikacją prac w okresie wiosenno-jesiennym, realizacja inwestycji w różnych miejscach poza siedzibą firmy, wpływ warunków atmosferycznych (np. w okresie zimowym) na zaplanowanie, zorganizowanie i wykonanie prac budowlanych.

9 W niniejszym opracowaniu, ze względu na objętość publikacji, pominięto analizę braku odpowiedzi. 
Tabela 3. Ocena wprowadzonych zmian wewnatrz organizacji

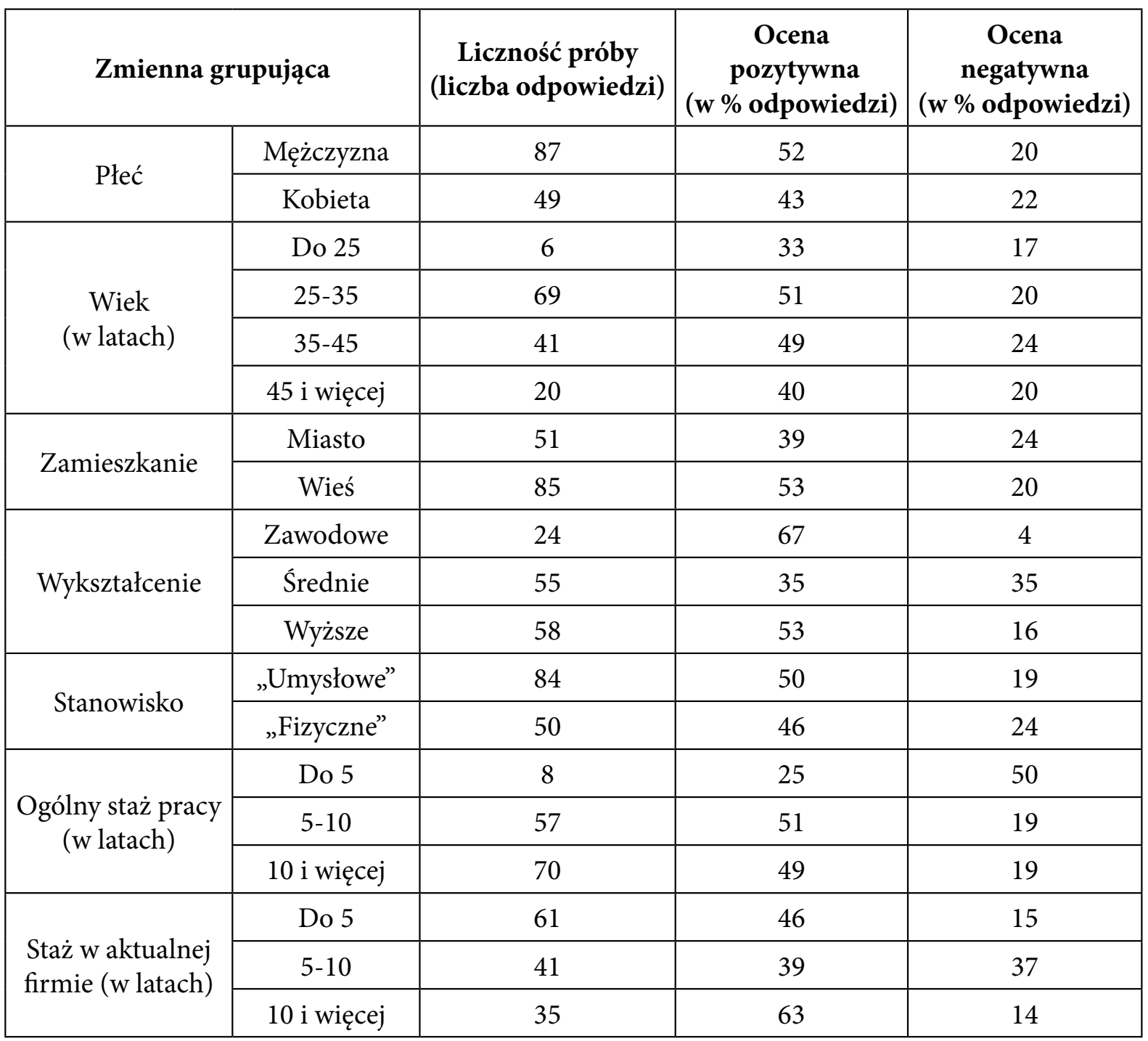

Źródło: opracowanie własne na podstawie wyników badań

Wprowadzone zmiany w poszczególnych obszarach zadaniowych przedsiębiorstwa podlegają ocenie przez uczestników tych zmian. Naturalnym zjawiskiem w procesie zmian wewnątrz organizacji jest fakt, iż z jednej strony zauważa się negatywne reakcje wśród pracowników spowodowane obawami przed tym co nieznane, a być może zupełnie nowe. $Z$ drugiej strony natomiast, jeżeli zmiany zostaną już wprowadzone i po pewnym czasie zaakceptowane przez pracowników - będą postrzegane pozytywnie. Analiza danych statystycznych zawartych w tabeli 3 wskazuje, iż spośród 87 przebadanych mężczyzn, $52 \%$ z nich oceniło zmiany pozytywnie (a $20 \%$ - negatywnie), zaś spośród 49 przebadanych kobiet, wewnętrzne zmiany in plus oceniło $43 \%$ (odmiennego zdania było 22\% kobiet). Co drugi z badanych (51\%) w wieku od 25 do 35 lat ocenił zmiany pozytywnie, a blisko co piąty (17\%) w wieku do 25 lat - negatywnie. Jeżeli chodzi o miejsce zamieszkania, pracownicy mieszkający na wsi wyżej ocenili zmiany in plus (53\%) wobec pracowników zamieszkujących w mieście (39\%). 
Ponadto $67 \%$ pracowników posiadających wykształcenie zawodowe oceniło zmiany pozytywnie, a co trzecia osoba (35\%) mająca wykształcenie średnie - negatywnie. Osoby z wyższym wykształceniem wskazały, iż w odczuciu ponad połowy z nich (53\%) zmiany należy ocenić pozytywnie, a odmienne stanowisko w tej kwestii zajęło 16\%. Dokładnie połowa pracowników zajmujących stanowiska „umysłowe” oceniła zmiany pozytywnie, zaś czterech na pięciu badanych (19\%) - negatywnie. Co ciekawe, jeżeli chodzi o ogólny staż pracy zawodowej, 50\% osób posiadających staż pracy do 5 lat oceniło zmiany negatywnie, a 50\% osób mających staż pracy powyżej 5 do 10 lat - pozytywnie. Jeżeli chodzi o staż pracy w aktualnej firmie, 63\% osób pracujących $\mathrm{w}$ badanych przedsiębiorstwach oceniło te zmiany pozytywnie, a w grupie osób mających staż pracy powyżej 5 do 10 lat, ocenę negatywną wystawiło $37 \%$ badanych.

Na podstawie uzyskanych odpowiedzi można wnioskować, iż respondenci zasadniczo korzystnie ocenili zmiany, z perspektywy pięciu lat wstecz, co zapewne wynikło $\mathrm{z}$ ich adaptacji do wprowadzonych $\mathrm{w}$ firmie zmian. Uzyskane opinie nie powinny zastanawiać. Skoro w branży budowlanej rotacja pracowników jest standardem (co potwierdziła kadra kierownicza badanych przedsiębiorstw), można domniemywać, iż zasadniczo osoby biorące udział w badaniach wykazywali się nie tylko lojalnością wobec pracodawcy, ale także odznaczali się umiejętnością dostosowania się do zmian.

\section{Podsumowanie}

Zmiany zachodzące wewnątrz organizacji mogą zostać zainicjowane przez nią samą lub wywołane przez jej otoczenie. Wprowadzane wewnątrz organizacji zmiany i reakcja na nie pracowników tych organizacji nabierają obecnie szczególnego znaczenia. W procesie zmian wewnątrzorganizacyjnych ludzie odgrywają decydującą rolę we wszystkich obszarach objętych zmianami.

Zaakcentować należy, iż procesy zachodzące w organizacjach powodują konieczność zmiany postrzegania zasobów ludzkich oraz rekonstrukcji zarządzania tymi zasobami (Miś, 2013, s. 7-8). Jest to o tyle istotna kwestia, że pracownicy mogą być albo przychylni wprowadzonym zmianom, albo niechętni tym zmianom $\mathrm{z}$ różnych względów (Bańka, 2011, s. 100), co w rezultacie przełoży się na działalność przedsiębiorstwa.

Niewątpliwie każda zmiana pociąga za sobą pewne koszty ponoszone przez pracowników. Dla jednych zmiana wewnątrz organizacji wiąże się np. ze zmianą wysokości wynagrodzenia, spowodowaną zmniejszeniem wymiaru czasu pracy czy też organizacji pracy. Dla innych może to być zmiana warunków pracy, a jeszcze inni zmuszeni są zmienić strukturę kwalifikacji/kompetencji zawodowych, co zostało udowodnione w toku przeprowadzonych badań.

Mimo wszystko zmiana stanowi wartość w/dla organizacji, będąc swoistego rodzaju złożonym zjawiskiem łatwiejszym do opisania post factum niż przed jej 
wystąpieniem, nawet wówczas, gdy jest planowana (Roszak, 2016, s. 58). Dlatego przetaczające się w literaturze dyskusje na temat zmian wewnątrzorganizacyjnych sprowadzają się do konkluzji, iż każdą zmianę powinno się gruntownie przemyśleć, zakomunikować, a dopiero wówczas zaimplementować w praktyce.

\section{BIBLIOGRAFIA}

[1] Antoszkiewicz J.D., 2008, Innowacje $w$ firmie. Praktyczne metody wprowadzania zmian, Poltext, Warszawa.

[2] BAŃKa W., 2011, Człowiek w organizacji, Adam Marszałek, Torun.

[3] Barańska D., 2014, Adaptacja pracowników do przekształceń w przedsiębiorstwach, Wydawnictwo Naukowo Techniczne, Warszawa.

[4] Cannon J.A., Mcgee R., 2015, Rozwój i zmiana organizacji, Wolters Kluwer, Warszawa.

[5] Czop K., 2001, Zjawisko zmian organizacyjnych, [w:] M. Brzeziński (red.), Zarządzanie innowacjami technicznymi i organizacyjnymi, Difin, Warszawa.

[6] Franciк A., 2003, Sterowanie procesami innowacyjnymi w organizacji, Akademia Ekonomiczna, Kraków.

[7] Huczeк M., 2011, Zarządzanie ryzykiem w innowacyjnej działalności organizacji, [w:] D. Fatuła (red.), Społeczne, marketingowe i innowacyjne aspekty kreowania zmian worganizacjach, Krakowskie Towarzystwo Edukacyjne - Oficyna Wydawnicza AFM, Kraków.

[8] JАвŁońsкi M., 2015, Struktura kompetencji pracowniczych do pracy $z$ informacjami, [w:] Ł. Jabłoński (red.), Konwergencja, kapitał ludzki, innowacje, CeDeWu, Warszawa.

[9] Milewska J., Woszczyk P., 2012, Od oporu do aktywnej partycypacji. Jak przygotować siebie i zespół do wprowadzenia zmiany?, „Personel i zarządzanie”, nr 11.

[10] Miś A., 2013, Wprowadzenie, [w:] A. Miś (red.), Instrumenty zarzadzania kapitałem ludzkim, Uniwersytet Ekonomiczny, Kraków.

[11] Mүјак T., 2014, Wpływ formy zatrudnienia na zachowania organizacyjne. Empiryczne studium porównawcze, Adam Marszałek, Torun.

[12] Myszka L., 2016, Znaczenie pracy i zawodu dla człowieka, [w:] J. Mółka (red.), Praca i rozwój człowieka, Wydawnictwo WAM, Kraków.

[13] Oczkowska R., 2014, Rozwój zasobów ludzkich - istota, instrumenty, podmioty, [w:] R. Oczkowska i U. Bukowska (red.), Rozwój zasobów ludzkich organizacji, Difin, Warszawa.

[14] Olejczyк-Kita K., 2016, Ciagła zmiana - czy zasoby stanowia barierę?, [w:] A. Jaki, M. Kowalik (red.), Procesy restrukturyzacji wobec współczesnych przemian gospodarczych, Fundacja Uniwersytetu Ekonomicznego, Kraków.

[15] Pachura A., Nitkiewicz T., Kuraś M., 2016, Zmiana a sukces organizacji - porównawcze studium przypadku wybranych przedsiębiorstw, [w:] A. Jaki, M. Kowalik (red.), Procesy restrukturyzacji wobec wspótczesnych przemian gospodarczych, Fundacja Uniwersytetu Ekonomicznego, Kraków.

[16] Roszak M., 2016, Zmiany, zmiany, zmiany..., „Problemy jakości”, nr 7-8.

[17] Soвка M., 2014, Zmiany organizacyjne w teorii i praktyce, Politechnika Lubelska, Lublin.

[18] Wolfram-Krukowska B., Ostrowska K., 2012, Kwadratura koła, czyli jak przeprowadzić organizację przez zmianę?, „Personel i zarządzanie”, nr 1.

[19] Zając Cz., 2006, Społeczne i organizacyjne problemy przejęć i fuzji przedsiębiorstw, Akademia Ekonomiczna, Wrocław. 